\title{
Can red deer antlers be used as an indicator of environmental and edible tissues' trace element contamination?
}

\author{
Aleksandra Giżejewska ${ }^{1}$ - Józef Szkoda ${ }^{2}$ - Agnieszka Nawrocka ${ }^{2}$. Jan Żmudzki ${ }^{2}$. \\ Zygmunt Giżejewski ${ }^{3}$
}

Received: 29 July 2016/Accepted: 9 March 2017 / Published online: 21 March 2017

(C) The Author(s) 2017. This article is published with open access at Springerlink.com

\begin{abstract}
Venison is an attractive product for consumers concerned with healthy lifestyle; however, it can contain high levels of toxic elements, and therefore, it is a possible source of hazardous contaminants in human diet. Antlers are suitable bioindicators of environmental metal contamination, and herein, we assessed the ability of trace element levels in antlers to indicate levels in edible soft tissues. We determined the concentrations of lead $(\mathrm{Pb})$, cadmium $(\mathrm{Cd})$, mercury $(\mathrm{Hg})$, arsenic $(\mathrm{As})$, copper $(\mathrm{Cu})$, zinc $(\mathrm{Zn})$, and iron $(\mathrm{Fe})$ in the liver, kidney, muscle, and antlers of 14 free-ranging red deer (Cervus elaphus) from northeastern Poland using atomic absorption spectrometry. We found the highest concentrations of $\mathrm{Pb}(0.321 \pm 0.165 \mathrm{mg} / \mathrm{kg})$, As $(0.045 \pm 0.074 \mathrm{mg} / \mathrm{kg}), \mathrm{Zn}(105.31 \pm 16.33 \mathrm{mg} / \mathrm{kg})$, and $\mathrm{Fe}$ $(220.92 \pm 117.18 \mathrm{mg} / \mathrm{kg})$ in antlers; of Cd $(4.974 \pm 1.90 \mathrm{mg} / \mathrm{kg})$ and $\mathrm{Hg}(0.048 \pm 0.102 \mathrm{mg} / \mathrm{kg})$ in kidney; and of $\mathrm{Cu}$ $(7.29 \pm 7.02 \mathrm{mg} / \mathrm{kg})$ in the liver. A positive relationship between concentrations in antlers and muscle was found only for $\mathrm{Cu}$ $(p=0.001)$, and it therefore appears that red deer antlers cannot
\end{abstract}

Józef Szkoda died before the publication of this paper.

Responsible editor: Philippe Garrigues

Electronic supplementary material The online version of this article (doi:10.1007/s11356-017-8798-7) contains supplementary material, which is available to authorized users.

Zygmunt Giżejewski

z.gizejewski@pan.olsztyn.pl

1 Department of Pharmacology and Toxicology, Faculty of Veterinary Medicine, University of Warmia and Mazury, Oczapowskiego 14, 10-719 Olsztyn, Poland

2 The National Veterinary Research Institute, 57 Partyzantów Avenue, 24-100 Puławy, Poland

3 Institute of Animal Reproduction and Food Research of Polish Academy of Sciences, Tuwima 10 Str, 10-748 Olsztyn, Poland be used as an index for element concentrations in soft tissues. While our results confirm that the Mazury region is little polluted, consumption of red deer offal from this area should be limited according to extant legal limits set for livestock consumption.

Keywords Toxic trace elements · Essential trace elements · Bioindicator $\cdot$ Pollution

\section{Introduction}

Despite modern technologies of exhaust gas purification, sewage treatment, and improvement of mining and metal processing methods, contaminants deposited in the environment in recent years remain of major concerns (EFSA 2009, 2010; Küttner et al. 2014). Toxic trace elements are present not only in the vicinity of industrial areas but also in natural and agricultural ecosystems away from emission sources (Giżejewska et al. 2015). Toxic trace elements such as lead (Pb), cadmium $(\mathrm{Cd})$, mercury (Hg), and arsenic (As) pose a health threat to organisms even in small doses. Although essential trace elements such as copper $(\mathrm{Cu})$, zinc $(\mathrm{Zn})$, or iron $(\mathrm{Fe})$ are necessary for growth and development of organisms, they may also pose a threat in high doses (Wasi et al. 2013).

Venison is an attractive product for consumers due to its nutritional properties, i.e., high protein and essential element content, optimal fatty acids, and low fat contents (Skibniewski et al. 2015). Most popular game species consumed in Europe are wild boar (Sus scrofa), roe deer (Capreolus capreolus), and red deer (Cervus elaphus; Falandysz et al. 2005; Ramanzin et al. 2010). In countries with hunting tradition, venison constitutes a large percentage of the annual meat consumption, and in Poland it was assessed as $80 \mathrm{~g}$ per capita per annum on average (Górecka and Szymańko 2010). In hunters' families, however, venison consumption can be much higher 
(e.g., 1-4 kg per capita per annum in Italy; Ramanzin et al. 2010). Edible tissues of free-living animals can contain higher levels of toxic trace elements than livestock and could therefore potentially be an important source of hazardous contaminants in human diet (Kramárová et al. 2005). Moreover, while maximum levels of toxic trace elements in animal products are set by the European Committee (EC) for livestock (bovine, sheep, pig, and poultry), there are no legal limits set for venison.

Liver and kidney being the most important organs responsible for detoxification, they most often are tissues of choice in analyses of environmental pollution levels (Stankovic et al. 2014). Contrastingly, cervid antlers have a number of advantages that make them a unique material for monitoring of trace contaminants (Giżejewska 2015; Giżejewska et al. 2016, 2015). Antlers are bony cephalic appendages that are cast and regenerated annually, with high demand for minerals in the growing period, during which they accumulate trace elements (Kierdorf and Kierdorf 2006). Antlers suitability for bioindication of current and retrospective environmental contamination by trace elements (Giżejewska 2015), fluoride (Kierdorf and Kierdorf 2006), and radionuclides (Baeza et al. 2011) has been demonstrated. Moreover, antlers are readily available when collected either as trophies during scheduled hunts or non-invasively when naturally cast antlers are recovered.

Red deer has many features of a good bioindicator species as (i) its biology is relatively well known; (ii) it has a relatively long life span; (iii) it is widespread in temperate latitudes, relatively sedentary, and can come close to human settlements; and (iv) it has a defined diet. If content of elements in red deer soft tissues could be predicted based on their levels in antlers, chemical analysis of antler composition would allow health risk assessment for consumers of red deer offal and meat. To our knowledge, there is no study assessing the relationships between trace element concentrations in red deer antlers and their levels in soft tissues. To address this research gap, (i) we determined the concentrations of $\mathrm{Pb}, \mathrm{Cd}, \mathrm{Hg}, \mathrm{As}, \mathrm{Zn}, \mathrm{Cu}$, and $\mathrm{Fe}$ in the liver, kidney, muscle tissue, and antlers of red deer hunted in an area regarded as little contaminated; (ii) we assessed the ability of trace element levels in antlers to indicate levels in edible soft tissues; and (iii) we evaluated the degree of contamination of red deer edible tissues, according to the EC limits set for livestock, with regard to the lack of an official threshold for wildlife.

\section{Materials and methods}

\section{Study area}

We investigated the levels of trace elements in red deer hunted in the Pisz Forest, Warmia and Mazury Region, north-eastern (NE) Poland $\left(21^{\circ} 32^{\prime} \mathrm{E}, 53^{\circ} 40^{\prime} \mathrm{N}\right.$; ca. $\left.170 \mathrm{~km}^{2}\right)$. The region is a traditional agricultural area with extensive continental and sub-continental mixed coniferous forests (31\% of the area), and numerous lakes. The region is an important recreational center for local and international tourists who seek activities in a natural environment. Pisz Forest is the largest forest complex in Mazury and the second largest in Europe. The sampling site was away from any major industrial complex as putative source of pollutants (Giżejewska et al. 2015) but was 20$30 \mathrm{~km}$ from a military training ground in Orzysz.

\section{Sampling}

We used tissue samples from 14 red deer stags culled in the hunting season 2013/2014 in accordance with current hunting plans and regulations. Age of the animals was from 4 to 11 years and was assessed based on teeth wear (Lowe 1967) and body weight. We collected ca. $300 \mathrm{~g}$ of liver, kidney (contain renal cortex and medulla), muscle (medial side of quadriceps femoris), and antler tissues from each individual. We sampled antlers using rechargeable hand drill fitted with vanadium drill (6-mm diameter). Before sampling, antlers were carefully cleaned with a nylon brush. Afterwards, a hole was drilled into the back of the beam approximately $6 \mathrm{~cm}$ into the brown tine (the first antler branch), $1.5 \mathrm{~cm}$ above the burr. Samples contained both compact and trabecular antler bone. To avoid secondary contamination of samples, the drill was rinsed in distilled water after each sample was collected. All samples were placed in separate polyethylene bags, then were frozen, and stored at $-20^{\circ} \mathrm{C}$ until analysis.

\section{Chemical analysis}

Homogenized samples were weighed in duplicate $(0.5-10 \mathrm{~g})$ and deposited in quartz crucibles, oven-dried overnight $\left(120 \pm 20^{\circ} \mathrm{C}\right)$, and then ashed in a muffle furnace at $450{ }^{\circ} \mathrm{C}$ for $24 \mathrm{~h}\left(550{ }^{\circ} \mathrm{C}\right.$ for As). All chemicals were of analytical grade. Concentrated nitric acid was added $(1 \mathrm{ml})$ to ashed samples, evaporated on a hot plate, and ashed again in the muffle furnace for about $1 \mathrm{~h}$. This last step was repeated until we obtained carbon-free ash (usually three times). In sample preparation for As analysis, 50\% v/v magnesium nitrate hexahydrate solution was added. Before analysis, samples were diluted in $0.2 \% v / v$ nitric acid (for $\mathrm{Pb}$ and $\mathrm{Cd}$ ) or $1 \mathrm{~N} \mathrm{HCl}$ (for other elements). We performed graphite furnace atomic absorption spectrometry to determine $\mathrm{Cd}$ and $\mathrm{Pb}$ concentrations using atomic absorption spectrometer Perkin-Elmer 4110 ZL (Szkoda and Żmudzki 2005). We used flame atomic absorption spectrometry with atomization in acetylene/air flame to determine $\mathrm{Cu}, \mathrm{Zn}$, and $\mathrm{Fe}$ concentrations using AVANTA PM (GBC, USA) spectrometer. Arsenic concentration was determined by hydride generation atomic absorption spectrometer PinAAcle 900T equipped in electrodeless discharge lamp (As EDL) and flow injection system FIAS 100 (PerkinElmer; Szkoda et al. 2006a). Concentrations of total $\mathrm{Hg}$ were determined using Advanced Mercury Analyzer 
AMA-254 (Altec Ltd., Czech Republic) performing atomic absorption spectrometry method, without prior sample mineralization (Szkoda et al. 2006b).

Analysis for each element was performed based on calibration curves plotted from blanks and working standard solutions. For calibration, we used commercial stock solutions (1000 $\mu \mathrm{g} / \mathrm{ml}$ ) of analytical grade for all four elements (J.T. Baker®). Calibration working standard solutions were 1$10 \mu \mathrm{g} / 1$ for $\mathrm{Cd}, 10-60 \mu \mathrm{g} / 1$ for $\mathrm{Pb}, 3-25 \mu \mathrm{g} / 1$ for As, $0.2-$ $3.0 \mu \mathrm{g} / \mathrm{ml}$ for $\mathrm{Cu}, 0.1-0.7 \mu \mathrm{g} / \mathrm{ml}$ for $\mathrm{Zn}$, and $0.5-3.0 \mu \mathrm{g} / \mathrm{ml}$ for $\mathrm{Fe}$. For $\mathrm{Hg}$ calibration, two ranges of working solution were made, which are $0.05-0.50$ and $1.0-5.0 \mu \mathrm{g} / \mathrm{ml}$. Limit of detection (LOD) and limit of quantitation (LOQ) were calculated as 3 and 10 times SD from results of blank matrix measurements $(n=10)$, respectively, with a low analyte content. LOD was established at the following levels $(\mathrm{mg} / \mathrm{kg})$ : for $\mathrm{Cd}$ and $\mathrm{Hg}$ 0.001, Pb and As 0.002, Cu 0.04, Zn 0.12, and Fe 0.11 . Reagent, calibration blanks, and control samples were prepared and run in triplicate. Calibration was periodically verified by analyzing a standard every 20 th reading.

Accuracy and precision of the method were confirmed by the analysis of certified reference materials (CRMs), bovine liver (BCR-185R, IRRM, Belgium), pig kidney (BCR-186, IRRM, Belgium), lobster hepatopancreas (TORT-2, NRCCNRC, Canada), and compound feed (IMEP-117, IRRM, Belgium). Recoveries of analyzed elements were within the range of $96-110 \%$, and relative standard deviations were below $10 \%$. We expressed element concentrations in milligrams per kilogram of wet weight (mg/kg w.w.).

\section{Statistical analysis}

For statistical analyses, concentrations below the LOD were assigned a value of half the LOD for each element (Reglero et al. 2008, 2009). To assess if concentrations in antlers could be used as an index of concentrations in soft tissues, we used linear regression of concentrations of a given trace element in a given soft tissue against its concentration in antlers. Because trace elements could bioaccumulate with age (López Alonso et al. 2004), we tested for additive and interactive effects of the age of the individuals. No age effect was detected and we report the results of univariate regression against concentration values in antlers. Statistical significance was set at $p<0.05$. All trace element concentration data were natural log-transformed to meet statistical assumptions. We conducted all statistical analyses using $\mathrm{R}$ version 3.0.0 (R Core Team 2013).

\section{Results}

Summary statistics of the concentrations of the seven trace elements analyzed in the four tissues are reported in Table 1. In the muscle tissue, $\mathrm{Pb}$ concentration in four samples $(0.082$,
$0.119,0.079$, and $0.570 \mathrm{mg} / \mathrm{kg}$ ) were higher than in the liver samples of the corresponding individuals $(0.020,0.015$, 0.027 , and $0.016 \mathrm{mg} / \mathrm{kg}$, respectively). These four muscle samples were excluded from the regression analysis against concentrations of $\mathrm{Pb}$ in antlers.

Simple linear regression to assess the use of trace element concentrations in antlers as an indicator of soft tissue contamination showed only a significant, positive relationship between $\mathrm{Cu}$ concentrations in antler and muscle tissue $\left(F_{1,12}=18.48, p=0.001, R^{2}=0.61\right.$; Fig. 1 and Table S1 $)$. Details of all other negative results are reported in Table S1.

Comparing concentrations of the four toxic trace elements to the maximum levels set by the European Commission for livestock, we found levels exceeding the norm in 2 muscle samples for $\mathrm{Pb}, 14$ (100\%) kidney samples for $\mathrm{Cd}$, and 3 liver and 3 kidney samples for $\mathrm{Hg}$ (Table 2).

\section{Discussion}

We tested whether antler chemical composition could be used as an index of trace elements in edible, soft tissues. The only significant relationship we found was between muscle tissue and antlers for $\mathrm{Cu}$. Therefore, it seems that only analyzing trace elements in antlers - that can be non-invasively collected once red deer naturally cast them annually - cannot be used as an indicator of trace element contaminations in edible tissues. Moreover, although animals for this study were sampled in a forest-dominated area, which derives considerable economic benefits from hunting, and considered to be little contaminated (Zalewski and Pacholska 2010; Giżejewska et al. 2015), we found several samples of soft tissues exceeding recommended levels for livestock consumption.

\section{Toxic trace elements}

\section{$\mathrm{Pb}$}

High $\mathrm{Pb}$ concentrations in antlers reflect its metabolism and chemical similarity to calcium, which causes $90 \%$ total body burden of $\mathrm{Pb}$ to accumulate in bone tissues as phosphates (Reglero et al. 2009). Antlers, due to their annual complete regrowth and high demand for minerals, therefore accumulate relatively high levels of $\mathrm{Pb}$.

In our study, $\mathrm{Pb}$ levels in the liver and kidney were low. Previous research conducted in NE Poland showed higher mean $\mathrm{Pb}$ levels in the liver, kidney, and muscle in both freeliving $(0.26,0.36,0.21 \mathrm{mg} / \mathrm{kg}$; Falandysz et al. 2005) and farmed $(0.700,0.384,0.388 \mathrm{mg} / \mathrm{kg}$; Drozd and Karpinski 1997) red deer, whereas in more recent studies, $\mathrm{Pb}$ values were in the same order of magnitude than ours $(0.17,0.30$, $0.18 \mathrm{mg} / \mathrm{kg}$ d.w. (Jarzyńska and Falandysz 2011); $0.10 \mathrm{mg} / \mathrm{kg}$ in muscles (Skibniewski et al. 2015)). This probably reflects 
Table 1 Mean concentrations and range (mg/kg w.w.) of seven elements in four tissues of red deer, NE Poland, 2013-2014

\begin{tabular}{|c|c|c|c|c|c|c|c|c|c|}
\hline \multirow[t]{2}{*}{ Element } & \multirow[t]{2}{*}{ Number } & \multicolumn{2}{|l|}{ Liver } & \multicolumn{2}{|l|}{ Kidney } & \multicolumn{2}{|l|}{ Muscle } & \multicolumn{2}{|l|}{ Antler } \\
\hline & & Mean \pm SD & Range & Mean \pm SD & Range & Mean \pm SD & Range & Mean \pm SD & Range \\
\hline $\mathrm{Pb}$ & 14 & $0.043 \pm 0.025$ & $0.012-0.103$ & $0.062 \pm 0.024$ & $0.034-0.109$ & $0.079 \pm 0.016$ & $0.006-0.570$ & $0.321 \pm 0.165$ & $0.093-0.649$ \\
\hline $\mathrm{Cd}$ & 14 & $0.256 \pm 0.089$ & $0.163-0.408$ & $4.974 \pm 1.90$ & $1.311-6.925$ & $0.006 \pm 0.003$ & $0.003-0.012$ & $0.011 \pm 0.004$ & $0.006-0.021$ \\
\hline $\mathrm{Hg}$ & 14 & $0.007 \pm 0.014$ & $<0.001-0.048$ & $0.048 \pm 0.102$ & $0.002-0.338$ & $0.001 \pm 0.000$ & $<0.001-0.002$ & $0.001 \pm 0.002$ & $<0.001-0.008$ \\
\hline As & 14 & $0.002 \pm 0.001$ & $<0.002-0.005$ & $0.003 \pm 0.002$ & $<0.002-0.007$ & $0.002 \pm 0.002$ & $<0.002-0.007$ & $0.045 \pm 0.074$ & $<0.002-0.237$ \\
\hline $\mathrm{Cu}$ & 14 & $7.29 \pm 7.02$ & $1.87-27.05$ & $4.08 \pm 0.45$ & $2.99-4.88$ & $1.10 \pm 0.35$ & $0.50-2.09$ & $3.14 \pm 0.86$ & $2.44-5.49$ \\
\hline $\mathrm{Zn}$ & 14 & $16.05 \pm 3.44$ & $11.01-23.27$ & $52.64 \pm 23.93$ & 26.31-92.46 & $67.14 \pm 15.67$ & $45.15-94.18$ & $105.31 \pm 16.33$ & $85.79-133.72$ \\
\hline $\mathrm{Fe}$ & 14 & $111.58 \pm 50.59$ & $34.08-195.16$ & $75.93 \pm 52.31$ & $9.02-188.99$ & $63.45 \pm 35.62$ & $22.49-152.53$ & $220.92 \pm 171.18$ & $41.77-594.72$ \\
\hline
\end{tabular}

the decrease of $\mathrm{Pb}$ levels in this region over time (Giżejewska 2015). Conversely, higher liver and kidney $\mathrm{Pb}$ concentrations were detected in red deer from mining $(0.430,0.805 \mathrm{mg} / \mathrm{kg}$ d.w.; Reglero et al. 2008, 2009) and hunting areas $(0.57$, $0.33 \mathrm{mg} / \mathrm{kg}$; Santiago et al. 1998) in Spain, historic Cu-NiFe ore smelting in Ontario $(1.47,1.95 \mathrm{mg} / \mathrm{kg}$; Parker and Hamr 2001), and hunting areas close to industrial centers in Slovakia (1.904, $0.561 \mathrm{mg} / \mathrm{kg}$; Kramárová et al. 2005). Data obtained in red deer from agricultural areas in Croatia (Lazarus et al. 2008; Bilandžić et al. 2009; Srebočan et al. 2012) were in the same order of magnitude as ours. Aerial borne particles are deposited on plant surface, and ingestion of contaminated vegetation represents the main source of $\mathrm{Pb}$ in herbivore (Srebočan et al. 2012). Additional sources are accidently or intentionally eaten soil and direct inhalation (Sheppard 2013).

In two muscle samples, we detected that $\mathrm{Pb}$ level exceeded the maximum threshold of $0.1 \mathrm{mg} / \mathrm{kg}$ recommended in farm animal edible tissues (Table 2; EC 2006). In four samples, $\mathrm{Pb}$ concentration was higher than in the liver, which likely indicated secondary contamination from $\mathrm{Pb}$ contained in ammunition (Szkoda et al. 2012). Against this background, these four samples were therefore excluded from the regression analysis while assessing the use of trace element concentrations in antlers as an index of concentration in muscle tissue. It has been shown that red deer muscle can be contaminated with $\mathrm{Pb}$ in the $30-\mathrm{cm}$ neighboring area of the bullet pathway (Dobrowolska and Melosik 2008). In human, a diet including venison with high $\mathrm{Pb}$ concentration can result up to 2.5 times higher $\mathrm{Pb}$ exposure to the consumer, when we compare it to the exposure of human living on normal diet (EFSA 2010).

\section{$C d$}

Cadmium, as well as $\mathrm{Zn}, \mathrm{Cu}$, or $\mathrm{Hg}$, can induce the metallothionein (MT) synthesis and is transported to kidneys as Cd-MT complex. In our study, the recommended maximum $1.0 \mathrm{mg} / \mathrm{kg}$ Cd limit (EC 2006) was exceeded in all 14 kidney samples (Table 2). In study conducted in another little contaminated area, this limit was exceeded in $68 \%$ of roe deer and $84 \%$ of red deer samples (Wieczorek-Dąbrowska et al. 2013).

Previous research conducted in NE Poland reported liver and kidney Cd levels of respectively $0.23,2.70 \mathrm{mg} / \mathrm{kg}$ (Falandysz et al. 2005) and $0.70,12.0 \mathrm{mg} / \mathrm{kg}$ d.w. (Jarzyńska and Falandysz 2011). This indicates a stable level of this element in red deer habitat in the Masurian region. Conversely, $\mathrm{Cd}$ concentrations in farmed deer were much lower (liver 0.039 , kidney 0.434 , muscle $0.005 \mathrm{mg} / \mathrm{kg}$; Drozd and Karpinski 1997), indicating the importance of dietary exposure; livestock do not eat perennial plants, which can accumulate higher contents of toxic elements.

Higher $\mathrm{Cd}$ contents in both liver and kidney were observed near an ore smelter in Ontario $(2.44,24.64 \mathrm{mg} / \mathrm{kg}$; Parker and Hamr 2001). Surprisingly, higher liver Cd levels were found in our study than in mining areas in Spain (Reglero et al. 2008, 2009), Poland (Szkoda et al. 2012), and Croatia (Lazarus et al. 2005, 2008; Bilandžić et al. 2009). Kidney $\mathrm{Cd}$ concentrations found in red deer in Slovakia (2.387 mg/kg; Gasparik et al. 2004) and in Spain $(2.16 \mathrm{mg} / \mathrm{kg}$; Santiago et al. 1998) were twice lower than our results. In the liver, those values were in the same order of magnitude as ours $(0.258 \mathrm{mg} / \mathrm{kg}$ (Gasparik et al. 2004); $0.21 \mathrm{mg} / \mathrm{kg}$ (Santiago et al. 1998)). This indicates long-term exposure to this element. Sewage sludge and mineral fertilizers applied on arable fields are important sources of chemical elements, including toxic ones (Wasi et al. 2013). Indirectly, this generates soil and water acidification, which increases solubility, and hence bioavailability of $\mathrm{Cd}$ and $\mathrm{Pb}$ for plants (Reglero et al. 2008). The importance of agriculture, as well as forestry, in our study area could therefore be an important source of trace element contamination in the natural environment, including $\mathrm{Cd}$.

In muscle tissue, this element is as low as in bone tissue. Mean Cd content in antlers was low at $0.011 \mathrm{mg} / \mathrm{kg}$. However, it has been shown that chronical exposure to $\mathrm{Cd}$ can influence bone tissue posing osteomalacia and osteoporosis (Chmielnicka and Cherian 1986; Wasi et al. 2013). 

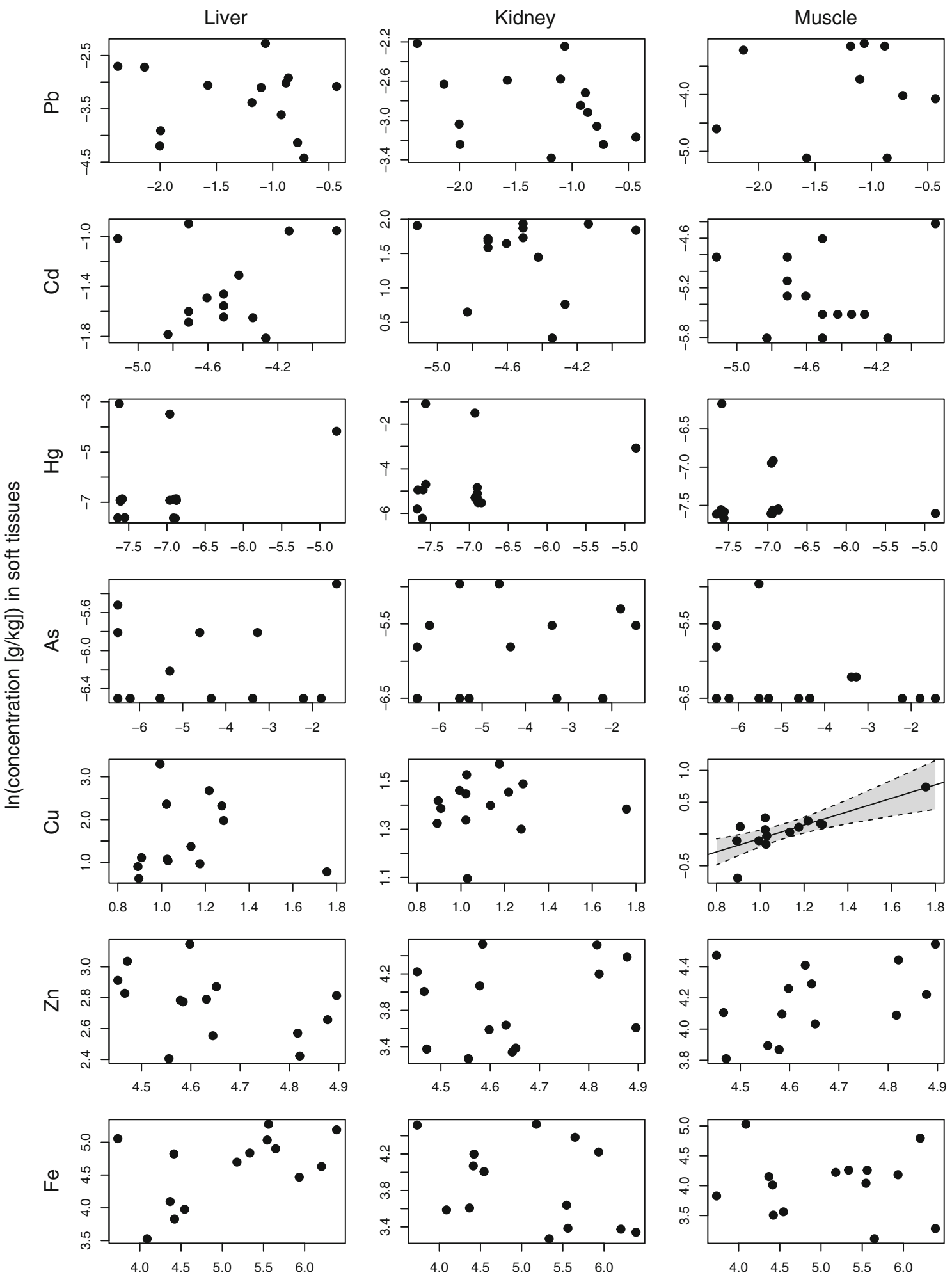

$\ln ($ concentration $[\mathrm{g} / \mathrm{kg}]$ ) in antlers

Fig. 1 Concentrations of the $\mathrm{Pb}, \mathrm{Cd}, \mathrm{Hg}, \mathrm{As}, \mathrm{Cu}, \mathrm{Zn}$, and $\mathrm{Fe}$ in three edible soft tissues of red deer against concentration in the antlers of 14 individuals hunted in Mazury, NE Poland, 2013/2014. The only significant relationship was between antler and muscle tissue concentration for $\mathrm{Cu}$. The solid represent the linear regression line, with the dotted line and shaded area depicting the 95\% confidence interval. Note that all data have been ln-transformed to meet statistical assumptions. Four muscle tissue samples likely contaminated by ammunition have been excluded of the analysis of $\mathrm{Pb}$ in muscle versus antlers 
Table 2 Comparison between element levels in the analyzed samples of red deer tissues from Mazury, NE Poland, 2013/2014, and the legal categories for each metal according the European Commission (EC 2006, 2008)

\begin{tabular}{lllllll}
\hline Maximum levels (MLs) in tissues (mg/kg) & $n$ & $<$ LOD & P5 & Median & P95 & $>$ ML \\
\hline $\mathrm{Pb}$ & & & & & & \\
Liver $0.5^{\mathrm{a}}$ & 14 & - & 0.014 & 0.046 & 0.080 & - \\
Kidney $0.5^{\mathrm{a}}$ & 14 & - & 0.037 & 0.056 & 0.107 & - \\
Muscle $0.1^{\mathrm{a}}$ & 14 & - & 0.006 & 0.021 & 0.277 & 2 \\
Antler & 14 & - & 0.110 & 0.339 & 0.540 & - \\
$\mathrm{Cd}$ & & & & & & \\
Liver $0.5^{\mathrm{a}}$ & 14 & - & 0.170 & 0.218 & 0.390 & - \\
Kidney $1.0^{\mathrm{a}}$ & 14 & - & 1.700 & 5.483 & 6.900 & 14 \\
Muscle $0.05^{\mathrm{a}}$ & 14 & - & 0.003 & 0.005 & 0.011 & - \\
Antler & 14 & - & 0.007 & 0.011 & 0.018 & - \\
Hg & & & & & & \\
Liver $0.01^{\mathrm{b}}$ & 14 & 4 & $<0.001$ & 0.001 & 0.036 & 3 \\
Kidney $0.01^{\mathrm{b}}$ & 14 & - & 0.003 & 0.007 & 0.026 & 3 \\
Muscle $0.01^{\mathrm{b}}$ & 14 & 11 & $<0.001$ & 0.001 & 0.001 & - \\
Antler & 14 & 6 & $<0.001$ & 0.001 & 0.003 & - \\
As & & & & & & - \\
Liver & 14 & 8 & 0.002 & 0.002 & 0.004 & - \\
Kidney & 14 & 6 & 0.002 & 0.003 & 0.007 & - \\
Muscle & 14 & 9 & 0.002 & 0.002 & 0.005 & - \\
Antler & 14 & 3 & 0.002 & 0.008 & 0.191 & - \\
\hline
\end{tabular}

$n$ number of samples, $P 55$ th percentile, $P 9595$ th percentile, $<L O D$ number of samples under limit of detection, $>M L$ number of samples over the maximum legal limit

${ }^{\mathrm{a}} \mathrm{EC} 2006$

${ }^{\mathrm{b}}$ EC 2008

\section{$H g$}

There are few studies concerning concentrations of $\mathrm{Hg}$ in herbivores' tissues. High $\mathrm{Hg}$ concentrations are rarely found in tissues of terrestrial animals, such contamination affecting mainly aquatic organisms. Target organs for this element are kidneys (long-term exposure) and the liver (short-term; Albińska et al. 2011). Higher kidney Hg level than in our study was found in Croatia $(0.375 \mathrm{mg} / \mathrm{kg})$ as a result of sediments and mud deposition on plants caused by flooding (Lazarus et al. 2005). Mercury is bound in the soil in insoluble compounds and is poorly absorbed by plants.

The highest environmental $\mathrm{Hg}$ deposition is present close to sources of emission and usually refers to accumulation in the local food chain (Gnamuš et al. 2000). Nevertheless, in southern Poland with high mining activity $(0.018 \mathrm{mg} / \mathrm{kg}$ (Dobrowolska and Melosik 2002); $0.022 \mathrm{mg} / \mathrm{kg}$ (Szkoda and Żmudzki 2001); 0.012-0.022 $\mathrm{mg} / \mathrm{kg}$ (Szkoda et al. 2012)), as well as in Croatia $(0.03 \mathrm{mg} / \mathrm{kg}$ (Lazarus et al. 2008); 0.011-0.018 mg/kg (Srebočan et al. 2012)), kidney $\mathrm{Hg}$ levels were lower than in our study. Conversely, kidney $\mathrm{Hg}$ levels were higher in industrial region in eastern Poland (Albińska et al. 2011) and mining area in Spain (Berzas Nevado et al. 2012). This shows the importance of bioavailability of element compound as well as differences among individuals of the same species.

Low $\mathrm{Hg}$ concentration $(0.001 \mathrm{mg} / \mathrm{kg})$ has been found in muscle tissue, even in animals collected in industrialized, mining areas in Poland (Szkoda and Żmudzki 2001; Szkoda et al. 2012), Spain (Berzas Nevado et al. 2012), and Croatia (Srebočan et al. 2012). Although Hg poorly accumulates in bone tissues, it was detected in all 14 antler samples.

In general, $\mathrm{Hg}$ levels in red deer demonstrate low exposure of free-living animals. Nevertheless, concentrations of $\mathrm{Hg}$ exceeding the maximum levels in three liver samples and one kidney sample (Table 2; EC 2008) of three specimens indicate individual variations in metal absorption and excretion.

As

The highest As level was found in antlers. Chemical similarity of arsenic to phosphorus compounds may explain the accumulation of As in bone tissues (Sharma et al. 2014). Higher As concentrations than in our study were obtained in liver of red deer from both mining and control areas in Spain (0.034 $0.061 \mathrm{mg} / \mathrm{kg}$ d.w.; Reglero et al. 2008, 2009). In Poland, especially in agricultural areas, use of pesticides and fertilizers 
represents the main source of As. Uptake of As by plant is generally low and depends on its compounds solubility, soil chemical composition, and vegetation species (Stankovic et al. 2014).

Analysis of As concentrations in red deer tissues collected as nationally representatives samples in Poland were low, $0.016 \mathrm{mg} / \mathrm{kg}$ in the liver, $0.005 \mathrm{mg} / \mathrm{kg}$ in kidney, and 0.001 in muscles (Szkoda and Żmudzki 2001). These values are well below the threshold recommended by European Food Safety Authority (EFSA 2009). We found 10 times lower liver As level than the mean value reported for deer elsewhere in Europe (0.02 mg/kg w.w.; Frøslie et al. 2001).

\section{Essential trace elements $(\mathrm{Cu}, \mathrm{Zn}, \mathrm{Fe})$}

Copper, as $\mathrm{Zn}$ and $\mathrm{Fe}$, is an essential trace element, and its status in organisms is restrictively regulated. The highest $\mathrm{Cu}$ concentration is found in the liver. In Mazury, mean liver $\mathrm{Cu}$ contents were $7.29 \mathrm{mg} / \mathrm{kg}$ (this work), $15 \mathrm{mg} / \mathrm{kg}$ (Falandysz et al. 2005), and $59 \mathrm{mg} / \mathrm{kg}$ d.w. (Jarzyńska and Falandysz 2011). Higher liver $\mathrm{Cu}$ concentrations were found in Norway (26.0 mg/kg; Vikøren et al. 2005), Croatia (14.7 mg/kg; Lazarus et al. 2008), Slovenia (13.342 mg/kg; Gasparik et al. 2004), and Spain (35.8-61.4 mg/kg d.w.), where comparison of $\mathrm{Cu}$ and $\mathrm{Zn}$ levels between contaminated and control regions showed no difference (Reglero et al. 2008). However, $\mathrm{Cu}$ values obtained in all studies from Europe were within the range given by Frøslie et al. (2001) for roe deer and red deer (4-30 mg/kg w.w.). Such a wide range of $\mathrm{Cu}$ concentrations shows individual variability and various demands of different organisms. Nevertheless, no individual showed visual sympthoms of $\mathrm{Cu}$ deficiency.

Unlike $\mathrm{Cu}, \mathrm{Zn}$ is easily absorbed by plants, which is the main source of this trace element for herbivores. Water contaminated with sewage or wastewater can also be an important source of Zn. Soil chemical analysis in 2005-2007 in NE Poland did not indicate $\mathrm{Cu}$ and $\mathrm{Zn}$ contamination (Terelak et al. 2008).

The highest $\mathrm{Zn}$ levels were found in antlers. This is consistent with $\mathrm{Zn}$ requirement for structure and function of alkaline phosphatase, an enzyme involved in bone mineralization. Liver $\mathrm{Zn}$ values obtained in this study were much lower than in cervids from unpolluted sites (70-113 mg/kg d.w.; Reglero et al. 2009), and kidney $\mathrm{Zn}$ level was in range reported by Frøslie et al. (2001). Surprisingly low concentration of $\mathrm{Zn}$ was found in red deer tissues in NW Poland (liver $11.62 \mathrm{mg} / \mathrm{kg}$, kidney $8.52 \mathrm{mg} / \mathrm{kg}$; Wieczorek-Dabrowska et al. 2013). It is worth to mention that there are much higher levels of $\mathrm{Cu}$ and $\mathrm{Zn}$ in liver and kidney of red deer from Ontario, Canada (Parker and Hamr 2001). That might be caused by differences in diet and presence of direct pollution source. Nevertheless, authors assessed their values as physiologically correct. Falandysz et al. (2005) reported liver and kidney levels of
$\mathrm{Cu}(1$ and $5 \mathrm{mg} / \mathrm{kg}$, respectively) and $\mathrm{Zn} \mathrm{(30} \mathrm{and} 31 \mathrm{mg} / \mathrm{kg}$, respectively) in red deer collected in the same region and stated as physiological levels. Levels of essential trace elements in wildlife should be interpreted locally, as an effect of adaptation to their environmental concentrations. Individual physiological state, sex, and age should be taken into account as well.

Different $\mathrm{Zn}$ levels were detected in red deer muscle from the same area, $22.33 \mathrm{mg} / \mathrm{kg}$ (Skibniewski et al. 2015), $40 \mathrm{mg} / \mathrm{kg}$ (Falandysz et al. 2005), $67.14 \mathrm{mg} / \mathrm{kg}$ (this study), and $150 \mathrm{mg} / \mathrm{kg}$ d.w. (Jarzyńska and Falandysz 2011). Nevertheless, red deer meat and offal is a good source of $\mathrm{Cu}$ and $\mathrm{Zn}$, as human daily demand for those elements is estimated to be $5 \mathrm{mg} \mathrm{Cu}$ and $10 \mathrm{mg} \mathrm{Zn} \mathrm{(Skibniewski} \mathrm{et} \mathrm{al.} \mathrm{2015).}$

Absorbed $\mathrm{Fe}$ is bound to transferrin. The amount of $\mathrm{Fe}$ which is not used directly for hemoglobin production is stored in the liver and bone marrow. Szkoda et al. (2004) reported that $\mathrm{Fe}$ concentrations of wild animals across Poland ranged from 3.64 to $170.3 \mathrm{mg} / \mathrm{kg}$ in the liver, from 51.81 to $200 \mathrm{mg} / \mathrm{kg}$ in the kidney, and from 5.15 to $70.08 \mathrm{mg} / \mathrm{kg}$ w.w. in the muscle tissue. Our results are within these ranges for each tissue as well as the data obtained in Croatia (Lazarus et al. 2005, 2008) and Canada (Parker and Hamr 2001). Lower kidney Fe was found in NW Poland (28.76 mg/kg; Wieczorek-Dąbrowska et al. 2013).

Concentration of essential trace elements obtained in our study of free-living red deer and comparison with the literature show great individual variation in this species. Lack of visual sympthoms of deficiency or intoxication indicates efficient mechanisms of homeostasis. Research projects in the same area on different species of wild animals (Falandysz et al. 2005; Giżejewska et al. 2015), soil samples (Terelak et al. 2008), and vegetation (Zalewski and Pacholska 2010) indicate that Mazury has low trace element contaminations.

\section{Conclusion}

Concentrations of $\mathrm{Pb}, \mathrm{Cd}, \mathrm{Hg}, \mathrm{As}, \mathrm{Cu}, \mathrm{Zn}$, and $\mathrm{Fe}$ in red deer antlers cannot be used to predict contaminations of soft tissues. However, we caution that the limited sample size in the current study does not allow for strong inference, and that further research might be warranted with larger sample size, and in different geographic areas. The need to directly analyze trace elements in soft tissues therefore remains to quantitatively assess potential levels of exposure in humans through consumption of venison. Anthropogenic pollution, areas naturally enriched in toxic trace elements, as well as increasing consumption of venison should be reasons to reconsider EC regulations (Lehel et al. 2016). Additionally, studies on $\mathrm{Hg}$ and As speciation are necessarily with regard to potential important implication for human health (Ropero et al. 2016). Comparison to levels recommended for livestock tissue consumption indicates that consumption of red deer offal should 
be limited according to possible contaminations we documented, especially for children, pregnant, and nursing women (Meltzer et al. 2013). Nevertheless, red deer meat is a good source of $\mathrm{Cu}, \mathrm{Zn}$, and Fe. Our results confirm that Mazury is little contaminated; however, concentrations of toxic elements in red deer tissues obtained from putatively unpolluted area call for regular monitoring of environmental pollutants.

Acknowledgements This study was funded by Ministry of Science and Higher Education research project Nr N N 308600939 entitled "Concentration of selected elements in red deer (Cervus elaphus) as an indicator of environmental contamination in the past 60 years." Results presented here are one of the aspects we studied in the project. We would like to thank the local hunting authorities, especially J. Kałaska and W. Kawecki, for their help in sample collection. Special thanks to J. Fattebert for the help with statistical analyses, and J. Kozak for the assistance with chemical analyses.

Open Access This article is distributed under the terms of the Creative Commons Attribution 4.0 International License (http:// creativecommons.org/licenses/by/4.0/), which permits unrestricted use, distribution, and reproduction in any medium, provided you give appropriate credit to the original author(s) and the source, provide a link to the Creative Commons license, and indicate if changes were made.

\section{References}

Albińska J, Góralski J, Szynkowska MI, Leśniewska E, Paryjczak T (2011) Mercury in carcasses of wild animals hunted in the province of Łódź. Rocz Ochr Sr 13:525-538 (in Polish)

Baeza A, Vallejo I, Guillén J, Salas A, Corbacho JA (2011) Antlers of Cervus elaphus as biomonitors of ${ }^{90} \mathrm{Sr}$ in the environment. J Environ Radioactiv 102:311-315

Berzas Nevado JJ, Martín-Doimeadios RCR, Mateo R, Rodríguez Fariñas N, Rodríguez-Estival J, Patiño Ropero MJ (2012) Mercury exposure and mechanism of response in large game using the Almadén mercury mining area (Spain) as a case study. Environ Res 112:58-66

Bilandžić N, Sedak M, Vratarić D, Perić T, Šimić B (2009) Lead and cadmium in red deer and wild boar from different hunting grounds in Croatia. Sci Total Environ 407:4243-4247

Chmielnicka J, Cherian MG (1986) Environmental exposure to cadmium and factors affecting trace-element metabolism and metal toxicity. Biol Trace Elem Res 10:243-262

R Core Team (2013) R: a language and environment for statistical computing. Foundation for Statistical Computing, Vienna, Austria. URL: http://www.R-project.ogr/

Dobrowolska A, Melosik M (2002) Mercury contents in liver and kidneys of wild boar (Sus scrofa) and red deer (Cervus elaphus). Z Jagdwiss 48:156-160

Dobrowolska A, Melosik M (2008) Bullet-derived lead in tissues of the wild boar (Sus scrofa) and red deer (Cervus elaphus). Eur J Wildlife Res 54:231-235

Drozd L, Karpinski M (1997) Heavy metal content in farming red deer (Cervus elaphus) and fallow deer (Dama dama) tissues. Annales UMCS sec. EE Zootechnica 15:309-314

EC (2006) Commission Regulation (EC) No 1881/2006 setting maximum levels of certain contaminations in foodstuff (L3 364/5)

EC (2008) Commission Regulation (EC) No 149/2008 amending Regulation (EC) No 396/2005 of the European Parliament and of the Council by establishing Annexes II, III and IV setting maximum residue levels for products covered by Annex I thereto

EFSA (2009) Scientific opinion on arsenic in food. Panel on Contaminants in the Food Chain (CONTAM). EFSA J. 7(10), 1351

EFSA (2010) Scientific opinion on lead in food. Panel on contaminants in the food chain (CONTAM). EFSA J 8(4):1570

Falandysz J, Szymczyk-Kobrzyńska K, Brzostowski A, Zalewski K, Zasadowski A (2005) Concentrations of heavy metals in the tissues of red deer (Cervus elaphus) from the region of Warmia and Mazury, Poland. Food Addit Contam 22:141-149

Frøslie A, Sivertsen T, Lochmiller R (2001) Perissodactyla and Artiodactyla. In: Shore RF, Rattner BA (eds) Ecotoxicology of wild mammals. John Wiley \& Sons Ltd., Chichester, pp 497-550

Gasparik J, Massanyi P, Slamecka J, Fabis M, Jurcik R (2004) Concentration of selected metals in liver, kidney, and muscle of the red deer (Cervus elaphus). J Environ Sci Health Part A 39: 2105-2111

Giżejewska A (2015) Concentration of selected elements in red deer (Cervus elaphus) antlers as an indicator of environmental pollution. $\mathrm{PhD}$ thesis, University of Warmia and Mazury, Olsztyn, Poland (in Polish with English summary)

Giżejewska A, Spodniewska A, Barski D, Fattebert J (2015) Beavers indicate metal pollution away from industrial centers in northeastern Poland. Environ Sci Pollut Res 22:3969-3975

Giżejewska A, Nawrocka A, Szkoda J, Żmudzki J, Jaroszewski J, Giżejewski Z (2016) Variations of selected trace element contents in two layers of red deer antlers. J Vet Res 60:467-471

Gnamuš A, Byrne AR, Horvat M (2000) Mercury in the soil-plant-deerpredator food chain of a temperate forest in Slovenia. Environ Sci Technol 34:3337-3345

Górecka J, Szymańko J (2010) Walory żywieniowe dziczyzny. Mag Przem Mięs 1-2:20-21 (in Polish)

Jarzyńska G, Falandysz J (2011) Selenium and 17 other largely essential and toxic metals in muscle and organ meats of red deer (Cervus elaphus) - consequences to human health. Environ Int 37:882-888

Kierdorf U, Kierdorf H (2006) Roe and red deer antlers as bioindicators of pollution of deer habitats by lead and fluoride. Vet Arhiv 76:117129

Kramárová M, Massanyi P, Jancova A, Toman R, Slamecka J, Tataruch F et al (2005) Concentration of cadmium in the liver and kidneys of some wild and farm animals. B Vet I Pulawy 49:465-469

Küttner A, Mighall TM, De Vleeschouwer F, Mauquoy D, Cortizas AM, Foster ID, Krupp E (2014) A 3300-year atmospheric metal contamination record from Raeburn flow raised bog, south West Scotland. J Archaeol Sci 44:1-11

Lazarus M, Vickovic I, Sostaric B, Blanusa M (2005) Heavy metal levels in tissues of red deer (Cervus elaphus) from eastern Croatia. Arh Za Hig Rada Toksikol Ind Hyg Toxicol 56:233-240

Lazarus M, Orct T, Blanuša M, Vicković I, Šoštarić B (2008) Toxic and essential metal concentrations in four tissues of red deer (Cervus elaphus) from Baranja, Croatia. Food Addit Contam Part A 25: 270-283

Lehel J, Laczay P, Gyurcsó A, Jánoska F, Majoros S, Lányi K, Marosán M (2016) Toxic heavy metals in the muscle of roe deer (Capreolus capreolus) — food toxicological significance. Environ Sci Pollut Res 23:4465-4472

López Alonso M, Montaña FP, Miranda M, Castillo C, Hernández J, Benedito JL (2004) Interactions between toxic (As, Cd, Hg and $\mathrm{Pb})$ and nutritional essential $(\mathrm{Ca}, \mathrm{Co}, \mathrm{Cr}, \mathrm{Cu}, \mathrm{Fe}, \mathrm{Mn}, \mathrm{Mo}, \mathrm{Ni}, \mathrm{Se}$, $\mathrm{Zn}$ ) elements in the tissues of cattle from NW Spain. Biometals 17: 389-397

Lowe VPW (1967) Teeth as indicators of age with special reference to red deer (Cervus elaphus) of known age from Rhum. J Zool 152:137153

Meltzer HM, Dahl H, Brantsæter AL, Birgisdottir BE, Knutsen HK, Bernhoft A, Oftedal B, Lande US, Alexander J, Haugen M, 
Ydersbond TA (2013) Consumption of lead-shot cervid meat and blood lead concentrations in a group of adult Norwegians. Environ Res 127:29-39

Parker GH, Hamr J (2001) Metal levels in body tissues, forage and fecal pellets of elk (Cervus elaphus) living near the ore smelters at Sudbury, Ontario. Environ Pollut 113:347-355

Ramanzin M, Amici A, Casoli C, Esposito L, Lupi P, Marsico G, Mattiello S, Olivieri O, Ponzetta MP, Russo C, Marinucci MT (2010) Meat from wild ungulates: ensuring quality and hygiene of an increasing resource. Ital J Anim Sci 9:318-331

Reglero MM, Monsalve-González L, Taggart MA, Mateo R (2008) Transfer of metals to plants and red deer in an old lead mining area in Spain. Sci Total Environ 406:287-297

Reglero MM, Taggart MA, Monsalve-González L, Mateo R (2009) Heavy metal exposure in large game from a lead mining area: effects on oxidative stress and fatty acid composition in liver. Environ Poll 157:1388-1395

Ropero MP, Fariñas NR, Mateo R, Nevado JB, Martín-Doimeadios RR (2016) Mercury species accumulation and trophic transfer in biological systems using the Almadén mining district (Ciudad Real, Spain) as a case of study. Environ Sci Poll Res 23:6074-6081

Santiago D, Motas-Guzman M, Reja A, Maria-Mojica P, Rodero B, Garcia-Fernandez AJ (1998) Lead and cadmium in red deer and wild boar from Sierra Morena Mountains (Andalusia, Spain). Bull Environ Contam Toxicol 61:730-737

Sharma AK, Tjell JC, Sloth JJ, Holm PE (2014) Review of arsenic contamination, exposure through water and food and low cost mitigation options for rural areas. Appl Geochem 41:11-33

Sheppard SC (2013) Transfer factors to whitetail deer: comparison of stomach-content, plant-sample and soil-sample concentrations as the denominator. J Environ Radioactiv 126:434-437

Skibniewski M, Skibniewska EM, Kośla T (2015) The content of selected metals in muscles of the red deer (Cervus elaphus) from Poland. Environ Sci Pollut R 22:8425-8431

Srebočan E, Janicki Z, Crnić AP, Tomljanović K, Šebečić M, Konjević D (2012) Cadmium, lead and mercury concentrations in selected red deer (Cervus elaphus L.) tissues from north-eastern Croatia. J Environ Sci Health Part A 47:2101-2108
Stankovic S, Kalaba P, Stankovic AR (2014) Biota as toxic metal indicators. Environ Chem Lett 12:63-84

Szkoda J, Żmudzki J (2001) Toxic elements in tissues of game animals. Med Weter 57:883-886 (in Polish)

Szkoda J, Żmudzki J (2005) Determination of lead and cadmium in biological material by graphite furnace atomic absorption spectrometry method. Bull Vet Inst Pulawy 49:89-92

Szkoda J, Żmudzki J, Grzebalska A (2004) Iron in animal tissue and milk. Rocz Panstw Zakl Hig 55:61-66 (in Polish)

Szkoda J, Żmudzki J, Grzebalska A (2006a) Determination of arsenic in biological material by hydride generation atomic absorption spectrometry method. Bull Vet Inst Puławy 50:269-272

Szkoda J, Żmudzki J, Grzebalska A (2006b) Determination of total mercury in biological material by atomic absorption spectrometry method. Bull Vet Inst Pulawy 50:363

Szkoda J, Durkalec M, Kołacz R, Żmudzki J (2012) Content of cadmium, lead and mercury in the tissues of game animals. Med Weter 68: 689-692 (in Polish)

Terelak H, Stuczyński T, Motowicka-Terelak T, Maliszewska-Kordybach B, Pietruch C (2008) Monitoring of the chemistry of Polish arable soil. Institute of Soil Science and Plant Cultivation State Research Institute, Pulawy (in Polish)

Vikøren T, Bernhoft A, Waaler T, Handeland K (2005) Liver concentrations of copper, cobalt, and selenium in wild norwegian red deer (Cervus elaphus). J Wildl Dis 41:569-579

Wasi S, Tabrez S, Ahmad M (2013) Toxicological effects of major environmental pollutants: an overview. Environ Monit Assess 185: 2585-2593

Wieczorek-Dąbrowska M, Tomza-Marciniak A, Pilarczyk B, Balicka-Ramisz A (2013) Roe and red deer as bioindicators of heavy metals contamination in north-western Poland. Chem Ecol 29:100-110

Zalewski K, Pacholska A (2010) Zawartość niektórych metali ciężkich w potencjalnym pokarmie bobra europejskiego (Castor fiber) na terenie Warmii i Mazur. In: Diagnozowanie Stanu Środowiska Naturalnego. Bydgoskie Towarzystwo Naukowe 2:325-338 (in Polish) 